\title{
Chemometric characterization of gamma irradiated chestnuts from Turkey
}

João C.M. Barreira, ${ }^{\mathrm{a}, \mathrm{d}}$, Amilcar L. Antonio ${ }^{\mathrm{a}, \mathrm{b}, \mathrm{c}}$, Tugba Günaydi ${ }^{\mathrm{e}}$, Hasan Alkan ${ }^{\mathrm{e}}$, Albino Bento $^{a}$, M. Luisa Botelho ${ }^{b}$, Isabel C.F.R. Ferreira, ${ }^{a}{ }^{*}$

${ }^{a}$ CIMO/Escola Superior Agrária, Instituto Politécnico de Bragança, Apartado 1172, 5301-855 Bragança, Portugal.

${ }^{b}$ GTRPP/Unidade de Física e Aceleradores, Instituto Tecnológico e Nuclear, Estrada Nacional 10, 2686-953 Sacavém, Portugal.

${ }^{c}$ Departamento de Física Fundamental, Universidade de Salamanca, Plaza de la Merced, 37008 Salamanca, Spain.

${ }^{d}$ REQUIMTE/Departamento de Ciências Químicas, Faculdade de Farmácia da Universidade do Porto, Rua Aníbal Cunha, 164, 4099-030 Porto, Portugal.

eGamma-Pak Sterilizasyon, 59500 Çerkezköy-Terkirdag, Turkey.

*Author to whom correspondence should be addressed (e-mail: iferreira@ipb.pt; telephone +351-273-303219; fax +351-273-325405). 


\begin{abstract}
Chestnut (Castanea sativa Miller) is a valuable natural resource, with high exportation levels. Due to their water content, chestnuts are susceptible to storage problems like dehydration or development of insects and microorganisms. Irradiation has been revealing interesting features to be considered as an alternative conservation technology, increasing food products shelf-life. Any conservation methodology should have a wide application range. Hence, and after evaluating Portuguese cultivars, the assessment of irradiation effects in foreign cultivars might act as an important indicator of the versatility of this technology. In this work, the effects of gamma irradiation $(0.0$, 0.5 and $3.0 \mathrm{kGy}$ ) on proximate composition, sugars, fatty acids (FA) and tocopherols composition of Turkish chestnuts stored at $4{ }^{\circ} \mathrm{C}$ for different periods $(0,15$ and 30 days) were evaluated. Regarding proximate composition, the storage time (ST) had higher influence than irradiation dose (ID), especially on fat, ash, carbohydrates and energetic value. Sucrose exhibited similar behavior in response to the assayed ST and ID. The prevalence of ST influence was also verified for FA, tocopherols and sucrose. Lauric, palmitoleic and linolenic acids, were the only FA that undergone some differences with ID. Saturated, monounsaturated and polyunsaturated fatty acids levels were not affected neither by storage nor irradiation. $\alpha$-Tocopherol was the only vitamer with significant differences among the assayed ST and ID. Overall, Turkish cultivars showed a compositional profile closely related with Portuguese cultivars, and seemed to confirm that gamma irradiation in the applied doses did not change chestnut chemical and nutritional composition.
\end{abstract}

Keywords: Castanea sativa Miller; Turkish chestnuts; gamma irradiation; chemometrics; storage time, HPLC 


\section{Introduction}

Chestnuts are an important food crop in southern Europe, southwestern and eastern Asia.

China is by far the largest producer country, followed by Korea, Italy, Turkey, Bolivia, Portugal and Japan (Peña-Méndez et al., 2008). Chestnuts have to be postharvest treated to increase their shelf-life due to the susceptibility to insect worms (Cydia splendana $\mathrm{Hb}$, Cydia fagliglandana Zel. and Curculio elephas Gyll), and fungi development, mainly Cyboria, which blackens the flesh, but also Rhizopus, Fusarium, Collectotrichum, and Phomopsis, causing high product losses during post-harvest period (Botondi et al., 2009). Different methods are being used to control insect invasion, such as fumigation $\left(\mathrm{CS}_{2}\right.$, phosphine, methyl bromide), low-temperature and controlled atmosphere storage, irradiation and submerging in icy water (Kwon et al., 2004). Fumigation with methyl bromide stills being the most common preservation method for chestnuts, but this toxic agent is used under strict control (Montreal Protocol) due to its adverse effects on human health and environment (UNEP, 1995; MBTOC, 1998). Food irradiation is a possible alternative to substitute the traditional quarantine chemical fumigation treatment (Kume et al., 2009; Legislation, 1994, 1995, 1999, 2003). Among the European major chestnut producers, Turkish chestnut cultivars are the ones with the scarcest characterization. In this work, Turkish chestnuts were evaluated for their proximate composition, FA, tocopherols and sugars profiles.

In addition to the well known health effects, FA play also an important role in chestnut conservation quality, since they contribute to develop desirable flavors and texture, besides defining the tendency for generating off-flavors upon oxidation of MUFAs (monounsaturated fatty acids) and PUFAs (polyunsaturated fatty acids). Tocopherols, which are powerful antioxidants, can stabilize FA and thus prevent the food rancidity or avoid the formation of undesirable chemical compounds that may be detrimental to health ( $\mathrm{Li}$ et al., 2007). Among sugars, sucrose is also important, being known as reliable parameter in the assessment of fruit quality, once sugar composition can be lowered or modified by storage temperature, relative humidity, harvest time, oxygen level or packaging (Kazantzis et al., 2003; Barreira et al., 2010). These compounds might be affected by the applied irradiation dose; otherwise, the dose must be sufficiently high to assure the elimination of the biological risks, so it is primarily essential to define the threshold values that prevent the development of undesirable physico-chemical changes.

Herein, the influence of gamma irradiation dose $(0.50$ and $3.00 \mathrm{kGy})$ and storage time (15 and 30 days) over the compositional features of Turkish chestnuts was evaluated, comparing with non irradiated and non stored control samples. This study comprises a new step in chestnuts global characterization, a research field with high interest for our investigation group (Barreira et al., 2008a, 2008b, 2009a, 2009b, 2010; Antonio et al., 2011; Fernandes et al., 2011).

\section{Experimental procedure}

\subsection{Standards and Reagents}

Acetonitrile $99.9 \%, n$-hexane $95 \%$ and ethyl acetate $99.8 \%$ were of HPLC grade from Lab-Scan (Lisbon, Portugal). The fatty acids methyl ester (FAME) reference standard mixture 37 (standard 47885-U) was purchased from Sigma (St. Louis, MO, USA), as also other individual fatty acid isomers, tocopherols and sugars standards. Racemic tocol, $50 \mathrm{mg} / \mathrm{ml}$, was purchased from Matreya (PA, USA). All other chemicals and solvents were of analytical grade and purchased from common sources. Water was treated in a Milli-Q water purification system (TGI Pure Water Systems, USA). 


\subsection{Samples and samples irradiation}

Turkish chestnuts samples were obtained in the local market and irradiated in an industrial unit (Gamma-Pak Sterilizasyon). They were divided in three groups, with fifteen units per group, to be exposed to different radiation doses $(0,0.5 \pm 0.1$ and $3.0 \pm$ $0.2 \mathrm{kGy}$ ) using the dose rate $1.13 \mathrm{kGy} / \mathrm{h}$.

\subsection{Proximate composition}

The samples were analysed for proximate composition (dry matter, proteins, fat, carbohydrates and ash) using the AOAC procedures (AOAC, 1995). The crude protein content of the samples was estimated by the macro-Kjeldahl method; the crude fat was determined by extracting a known weight of powdered sample with petroleum ether, using a Soxhlet apparatus; the ash content was determined by incineration at $600 \pm 15^{\circ} \mathrm{C}$. Total carbohydrates were calculated by difference. Total energy was calculated according to the following equations: Energy ( $\mathrm{kcal})=4 \times(\mathrm{g}$ proteins $+\mathrm{g}$ carbohydrates $)$ $+9 \times(\mathrm{g}$ fat $)$.

\subsection{Analysis of fatty acids}

FA were determined by gas-liquid chromatography with flame ionization detection (GC-FID)/capillary column as described previously by the authors (Fernandes et al., 2011) after a trans-esterification. The FA profile was analyzed with a DANI model GC 1000 instrument equipped with a split/splitless injector, a flame ionization detector (FID) and a Macherey-Nagel column $(30 \mathrm{~m} \times 0.32 \mathrm{~mm}$ ID $\times 0.25 \mu \mathrm{m} \mathrm{d}$ ). The oven temperature program was as follows: the initial temperature of the column was $50{ }^{\circ} \mathrm{C}$, held for $2 \mathrm{~min}$, then a $30^{\circ} \mathrm{C} / \mathrm{min}$ ramp to $125^{\circ} \mathrm{C}, 5{ }^{\circ} \mathrm{C} / \mathrm{min}$ ramp to $160{ }^{\circ} \mathrm{C}, 20^{\circ} \mathrm{C} / \mathrm{min}$ ramp to $180{ }^{\circ} \mathrm{C}, 3{ }^{\circ} \mathrm{C} / \mathrm{min}$ ramp to $200{ }^{\circ} \mathrm{C}, 20^{\circ} \mathrm{C} / \mathrm{min}$ ramp to $220{ }^{\circ} \mathrm{C}$ and held for 15 min. The carrier gas (hydrogen) flow-rate was $4.0 \mathrm{ml} / \mathrm{min}(0.61 \mathrm{bar})$, measured at $50^{\circ} \mathrm{C}$. Split injection $(1: 40)$ was carried out at $250{ }^{\circ} \mathrm{C}$. For each analysis $1 \mu \mathrm{l}$ of the sample was injected in GC. FA identification was done by comparing the relative retention times of FAME peaks from samples with standards. The results were recorded and processed using CSW 1.7 software (DataApex 1.7) and expressed in relative percentage of each FA.

\subsection{Analysis of tocopherols}

Tocopherols content was determined following a procedure previously described by the authors (Fernandes et al., 2011). The high-performance liquid chromatography (HPLC) equipment consisted of an integrated system with a pump (Knauer, Smartline system 1000), degasser system (Smartline manager 5000), auto-sampler (AS-2057 Jasco) coupled to a fluorescence detector (FP-2020; Jasco) programmed for excitation at 290 $\mathrm{nm}$ and emission at $330 \mathrm{~nm}$. The chromatographic separation was achieved with a Polyamide II $(250 \times 4.6 \mathrm{~mm})$ normal-phase column from YMC Waters operating at 30 ${ }^{\circ} \mathrm{C}$. The mobile phase used was a mixture of n-hexane and ethyl acetate $(70: 30, \mathrm{v} / \mathrm{v})$ at a flow rate of $1 \mathrm{ml} / \mathrm{min}$, and the injection volume was $20 \mu \mathrm{l}$. The compounds were identified by chromatographic comparisons with authentic standards. Quantification was based on the fluorescence signal response, using the internal standard method. Tocopherol contents in the samples are expressed in mg per $100 \mathrm{~g}$ of dry weight $(\mathrm{dw})$.

\subsection{Analysis of free sugars}


Free sugars were determined by HPLC described above coupled to a refraction index (Knauer Smartline 2300) detector as described by authors (Barreira et al., 2010). Data were analysed using Clarity 2.4 Software (DataApex). The chromatographic separation was achieved with a Eurospher 100-5 $\mathrm{NH}_{2}$ column $(4.6 \times 250 \mathrm{~mm}, 5 \mathrm{~mm}$, Knauer $)$ operating at $30{ }^{\circ} \mathrm{C}$ (7971 R Grace oven). The mobile phase was acetonitrile/deionized water, 7:3 (v/v) at a flow rate of $1 \mathrm{ml} / \mathrm{min}$. Sugar identification was made by comparing the relative retention times of sample peaks with standards. Quantification was made by internal normalization of the chromatographic peak area and the results are expressed in g per $100 \mathrm{~g}$ of dry weight $(\mathrm{dw})$.

\subsection{Statistical analysis}

An analysis of variance (ANOVA) with Type III sums of squares was performed using the GLM (General Linear Model) procedure of the SPSS software, version 18.0 (SPSS, Inc.). The dependent variables were analyzed using 2-way ANOVA, with the main factors "irradiation dose" (ID) and "storage time" (ST). When a (ID $\times S T)$ was detected, the two factors were evaluated simultaneously by the estimated marginal means plots for all levels of each single factor. Alternatively, if no statistical significant interaction was verified, means were compared using Tukey's honestly significant difference (HSD) multiple comparison test.

In addition, a linear discriminant analysis (LDA) was used to verify if the differences induced by storage time or gamma irradiation in sugars, FA and tocopherols composition were strong enough to have discriminant power. A stepwise technique, using the Wilks' $\lambda$ method with the usual probabilities of $F$ (3.84 to enter and 2.71 to remove) was applied for variable selection. This procedure uses a combination of forward selection and backward elimination procedures, where before selecting a new variable to be included, it is verified whether all variables previously selected remain significant (Maroco, 2003; López et al., 2008). With this approach, it is possible to identify the significant variables obtained for each sample. To verify which canonical discriminant functions were significant, the Wilks' $\lambda$ test was applied. A leaving-oneout cross-validation procedure was carried out to assess the model performance.

All the assays were carried out in triplicate.

\section{Results and discussion}

Table 1 shows the proximate and sucrose compositions and energetic value data reported as mean value of each irradiation dose (ID) over storage time (ST), as well as mean value of ID within each ST. Since sucrose was the only quantifiable sugar in the samples, it has been included in table 1. ST $\times$ ID interaction was a significant source of variation only for dry matter. Overall, the ST exerted a higher influence, since irradiation dose was never significant $(p>0.05)$. Further than the tabled homogeneous subgroups (Tukey's test), the comparison based on the analysis of the plots of the estimated margins means indicated that dry matter was higher for 30 days. No additional trends could be found for the remaining parameters. The tabled data seem to indicate that irradiation (until the tested doses) did not affect Turkish chestnut proximate composition. This conclusion was confirmed in the performed LDA, particularly in the leaving-one-out cross-validation procedure, in which only $44.4 \%$ of original grouped cases as well as of cross-validates grouped cases were correctly classified, considering the applied ID. In other way, when the samples were compared based on the ST, $83.3 \%$ of the original grouped cases and $81.5 \%$ of the cross-validates grouped cases were properly classified. 
Table 2 shows the FA profiles data reported as mean value of each ID over ST as well as mean value of all ID within each ST. The results show that ID $\times$ ST was a significant $(p \leq 0.027)$ source of variation for the all FA except C16:1 $(p=0.556), \mathrm{C} 18: 0(p=$ $0.862)$ and $\mathrm{C} 18: 3 \mathrm{n} 3(p=0.359)$. The main factor ID had no significant influence on $\mathrm{C} 16: 0(p=0.089), \mathrm{C} 16: 1(p=0.084), \mathrm{C} 17: 0(p=0.068), \mathrm{C} 18: 2 \mathrm{n} 6(p=0.076), \mathrm{C} 20: 0$ ( $p$ $=0.213)$ and $\mathrm{C} 22: 0(p=0.458)$, while ST showed higher influence, exerting a significant effect for all FA except C14:0 $(p=0.267), \mathrm{C} 16: 0(p=0.470), \mathrm{C} 20: 0(p=$ $0.230)$ and SFA $(p=0.100)$, indicating again that ST induce more compositional changes than ID. In fact, the performed multiple comparisons pointed out some differences among ST, but high similarity among ID, except in the case of C18:3n3. Even after the analysis of the plots of the estimated margins means for each proximate variable, it was only possible to found differences in C12:0 and C16:1, that were higher for $3 \mathrm{kGy}$ irradiated samples, C20:1, which was lower for $3 \mathrm{kGy}$ and $\mathrm{C} 22: 0$, that presented higher values after 15 days of storage. These particular differences were reflected in the LDA, where the leaving-one-out cross-validation procedure classified correctly $51.9 \%$ of original grouped cases as well as of cross-validates grouped, considering the applied ID; the values obtained for storage time also confirmed the found differences, since the leaving-one-out cross-validation procedure classified properly $87.0 \%$ of original grouped cases and $75.9 \%$ of cross-validates grouped. Furthermore, these results highlighted that Turkish chestnut present mainly three FA: linoleic, C18:2, $(44 \pm 2$ to $47 \pm 3)$, oleic, C:18:1, $(30 \pm 4$ to $34 \pm 2)$ and palmitic, C:16:0, $(13 \pm 1$ to $14 \pm 1)$ acids, accounting for more than $90 \%$ of the total FA content, a value similar to Portuguese cultivars (Borges at al., 2007; Barreira et al., 2009). Beyond the tabled FA, 5 more were quantified: C8:0, C12:0, C15:0, C20:2 and C20:3n3, but only in trace $(<0.1 \%)$ amounts.

Table 3 shows the tocopherols profiles data reported as mean value of each ID over ST as well as mean value of all ID within each ST. The results show that ID $\times$ ST acts as a significant source of variation for $\gamma$-tocopherol and $\delta$-tocopherol, but not for $\alpha$ tocopherol $(p=0.970)$, while ID was only significant for $\alpha$-tocopherol and ST influenced significantly $\alpha$-tocopherol and $\delta$-tocopherol. No particular tendency could be observed for $\gamma$-tocopherol and $\delta$-tocopherol, even after the analysis of the plots of the estimated margins means. However the qualitative and quantitative profile is very similar to the obtained for Portuguese cultivars $(\gamma$-tocopherol $>\delta$-tocopherol $>\alpha$ tocopherol) (Kazantzis et al., 2003).

In order to obtain a better understanding of the changes caused either by ST or ID, several combinations of parameters (proximate composition, FA or tocopherols) were tested through LDA. Besides the already presented results, the best outcome was obtained when all the parameters were assayed together to check the influence of ST. (Figure 1A). In this case, the leaving-one-out cross-validation procedure classified properly $96.3 \%$ of original grouped cases and $90.7 \%$ of cross-validates, proving the discriminant ability of the changes induced by ST, as also the importance of FA, since 6 of the 8 variables selected in the analysis were FA. However, the separation was lesser effective regarding ID, since only $66.7 \%$ of original grouped cases and $63.0 \%$ of crossvalidates cases were correctly classified (Figure 1B).

\section{Conclusions}

The storage time (ST) had higher influence than irradiation dose (ID), especially on fat, ash, carbohydrates and energetic value. The prevalence of ST influence was also verified for FA, tocopherols and sucrose. Lauric, palmitoleic and linolenic acids, were the only FA that undergone some differences with ID. Saturated, monounsaturated and 
polyunsaturated FA levels were not affected neither by storage nor irradiation. $\alpha$ Tocopherol was the only vitamer with significant differences among the assayed ST and ID. Overall, Turkish cultivars presented a typical chemical and nutritional profile, with slight differences when compared to Portuguese (Borges at al., 2007; Barreira et al., 2009a, 2009b, 2010) or Spanish (Míguelez et al., 2004; Pereira-Lorenzo at al., 2005) cultivars. Furthermore, this report confirms our previous results in Portuguese samples (Fernandes et al., 2011) as Turkish chestnuts proved to be hardly susceptible to gamma irradiation and more dependent on the storage time, highlighting the potential use of gamma irradiation without affecting chestnuts chemical and nutritional composition.

\section{Acknowledgements}

The authors thank to QREN/EU Project $n^{\circ} 13198 / 2010$, for financial support. J.C.M. Barreira and A.L. Antonio thank to FCT, POPH-QREN and FSE for their grants (SFRH/BPD/72802/2010 and SFRH/PROTEC/67398/2010, respectively).

\section{References}

AOAC, 1995. Official methods of analysis (16 ${ }^{\text {th }}$ Ed.). Arlington VA, USA: Association of Official Analytical Chemists.

Antonio, A.L., Fernandes, Â., Barreira, J.C.M., Bento, A., Botelho, M.L., Ferreira, I.C.F.R., 2011. Influence of gamma irradiation in the antioxidant potential of chestnuts (Castanea sativa Mill.) fruits and skins. Food Chem. Toxicol. doi:10.1016/j.fct.2011.02.016.

Barreira, J.C.M., Ferreira, I.C.F.R., Oliveira, M.B.P.P., Pereira, J.A., 2008. Antioxidant activity and bioactive compounds of ten Portuguese regional and commercial almond cultivars. Food Chem. Toxicol. 46, 2230-2235.

Barreira, J.C.M., Ferreira, I.C.F.R., Oliveira, M.B.P.P., Pereira, J.A., 2008. Antioxidant activities of the extracts from chestnut flower, leaf, skins and fruit. Food Chem. 107, 1106-1113.

Barreira, J.C.M., Alves, R.C., Casal, S., Ferreira, I.C.F.R., Oliveira, M.B.P.P, Pereira, J.A., 2009. Vitamin E profile as a reliable authenticity discrimination factor between Chestnut (Castanea sativa Mill.) cultivars. J. Agric. Food Chem. 57, 55245528.

Barreira, J.C.M., Casal, S., Ferreira, I.C.F.R., Oliveira, M.B.P.P., Pereira, J.A., 2009. Nutritional, fatty acid and triacylglycerol profiles of Castanea sativa Mill. cultivars: A compositional and chemometric approach. J. Agric. Food Chem. 57, 2836-2842.

Barreira, J.C.M., Pereira, J.A., Oliveira, M.B.P.P., Ferreira, I.C.F.R., 2010. Sugars profiles of different chestnut (Castanea sativa Mill.) and almond (Prunus dulcis) cultivars by HPLC-RI. Plant Foods Hum. Nutr. 65, 38-43.

Borges, O.P., Carvalho, J.S., Correia, P.R., Silva, A.P., 2007. Lipid and fatty acid of profiles of Castanea sativa Mill. chestnuts of 17 native Portuguese cultivars. J. Food Compos. Anal. 20, 80-89.

Botondi, R., Vailati, M., Bellincontro, A., Massantini, R., Forniti, R., Mencarelli, F., 2009. Technological parameters of water curing affect postharvest physiology and storage of marrons (Castanea sativa Mill., Marrone fiorentino). Postharvest Biol. Tec. 51, 97-103.

Fernandes, Â., Barreira, J.C.M., Antonio, A.L., Bento, A., Botelho, M.L., Ferreira, I.C.F.R., 2011. Assessing the effects of gamma irradiation and storage time in energetic value and in major individual nutrients of Castanea sativa Miller. J. Agric. Food Chem. Submitted. 
Kazantzis, I., Nanos, G.D., Stavroulakis, G.G., 2003. Effect of harvest time and storage conditions on almond kernel oil and sugar composition. J. Sci. Food Agric. 83, 354359.

Kume, T., Furuta, M., Todoriki, S., Uenoyama, N., Kobayashi, Y., 2009. Status of food irradiation in the world. Rad. Phys. Chem. 78, 222-226.

Kwon, J.-H., Kwon, Y.-J., Byun, M.-W., Kim, K.-S., 2004. Competitiveness of gamma irradiation with fumigation for chestnuts associated with quarantine and quality security. Rad. Phys. Chem. 71, 41-44.

Legislation: WHO, 1994; UNEP, 1995; 1999/2/EC, 1999; CAC/RCP 19-1979 rev. 2, 2003.D, 2004; CAC/RCP 19-1979 rev. 2, 2003.

Li, L., Tsao, R., Yang, R., Kramer, J.K.G., Hernandez, M., 2007. Fatty acid profiles, tocopherol contents, and antioxidant activities of heartnut (Juglans ailanthifolia Var. cordiformis) and Persian walnut (Juglans regia L.). J. Agric. Food. Chem. 55, 1164-1169.

López, A., García, P., Garrido, A., 2008. Multivariate characterization of table olives according to their mineral nutrient composition. Food Chem. 106, 369-378.

Maroco, J., 2003. Análise Estatística, com utilização do SPSS. Edições Sílabo, Lisboa, Portugal.

MBTOC - Methyl Bromide Technical Commitee - Marcotte, 1998.

Míguelez, J.M., Bernárdez, M.M, Queijeiro, J.M.G., 2004. Composition of varieties of chestnuts from Galicia (Spain). Food Chem. 84, 401-404.

Peña-Méndez, E.M., Hernández-Suárez, M., Díaz-Romero, C., Rodríguez-Rodríguez, E., 2008. Characterization of various chestnut cultivars by means of chemometrics approach. Food Chem. 107, 537-544.

Pereira-Lorenzo, S., Ramos-Cabrer, A.M., Díaz-Hernández, M.B., Ciordia-Ara, M., Ríos-Mesa, D., 2005. Chemical composition of chestnut cultivars from Spain. Sci. Hortic. 107, 306-314.

Stewart, E.M., 2001. In Food irradiation: principles and applications (R.A. Mollins ed.), 37-76.

UNEP - United Nations Environment Program - UNEP, 1995. 
Table 1. Proximate and sucrose composition of Turkish chestnuts according with irradiation dose (ID) and storage time (ST).

\begin{tabular}{|c|c|c|c|c|c|c|c|c|}
\hline & & $\begin{array}{c}\text { Dry matter } \\
(\mathrm{g} / 100 \mathrm{~g} \mathrm{fw})\end{array}$ & $\begin{array}{c}\text { Fat } \\
(\mathrm{g} / 100 \mathrm{~g} \mathrm{dw})\end{array}$ & $\begin{array}{c}\text { Protein } \\
(\mathrm{g} / 100 \mathrm{~g} \mathrm{dw})\end{array}$ & $\begin{array}{c}\text { Ash } \\
(\mathrm{g} / 100 \mathrm{~g} \mathrm{dw})\end{array}$ & $\begin{array}{c}\text { Carbohydrates } \\
(\mathrm{g} / 100 \mathrm{~g} \mathrm{dw})\end{array}$ & $\begin{array}{c}\text { Sucrose } \\
(\mathrm{g} / 100 \mathrm{~g} \mathrm{dw})\end{array}$ & $\begin{array}{l}\text { Energetic value } \\
(\mathrm{kcal} / 100 \mathrm{~g} \mathrm{dw})\end{array}$ \\
\hline \multirow{4}{*}{ ST } & 0 days & $49 \pm 2$ & $2.3 \pm 0.3 \mathrm{a}$ & $5 \pm 1$ & $2.3 \pm 0.1 \mathrm{~b}$ & $92 \pm 1 \mathrm{~b}$ & $38 \pm 4 \mathrm{a}$ & $410 \pm 2 \mathrm{a}$ \\
\hline & 15 days & $51 \pm 2$ & $2.1 \pm 0.5 \mathrm{ab}$ & $5 \pm 1$ & $2.6 \pm 0.4 \mathrm{a}$ & $93 \pm 1 \mathrm{ab}$ & $35 \pm 5 \mathrm{~b}$ & $410 \pm 2 \mathrm{ab}$ \\
\hline & 30 days & $54 \pm 2$ & $1.9 \pm 0.4 \mathrm{~b}$ & $5 \pm 1$ & $2.3 \pm 0.2 \mathrm{~b}$ & $93 \pm 1 \mathrm{a}$ & $38 \pm 4 \mathrm{a}$ & $408 \pm 2 b$ \\
\hline & $p$-value $(\mathrm{n}=54)$ & $<0.001$ & 0.012 & 0.110 & 0.004 & 0.004 & 0.004 & 0.015 \\
\hline \multirow{4}{*}{ ID } & $0.00 \mathrm{kGy}$ & $52 \pm 2$ & $2.2 \pm 0.4$ & $5 \pm 1$ & $2.4 \pm 0.2$ & $92 \pm 1$ & $35 \pm 4 \mathrm{~b}$ & $410 \pm 2$ \\
\hline & $0.50 \mathrm{kGy}$ & $52 \pm 4$ & $2.0 \pm 0.4$ & $5 \pm 1$ & $2.5 \pm 0.5$ & $92 \pm 1$ & $39 \pm 3 \mathrm{a}$ & $409 \pm 2$ \\
\hline & $3.00 \mathrm{kGy}$ & $51 \pm 2$ & $2.0 \pm 0.4$ & $5 \pm 1$ & $2.4 \pm 0.2$ & $92 \pm 1$ & $37 \pm 5 \mathrm{ab}$ & $409 \pm 2$ \\
\hline & $p$-value $(\mathrm{n}=54)$ & 0.054 & 0.257 & 0.744 & 0.522 & 0.527 & $<0.001$ & 0.252 \\
\hline ST $\times$ ID & $p$-value & $<0.001$ & 0.587 & 0.129 & 0.234 & 0.399 & 0.077 & 0.547 \\
\hline
\end{tabular}

Table 2. Composition in fatty acids (percentage) of Turkish chestnuts according with irradiation dose (ID) and storage time (ST) (mean \pm SD).

\begin{tabular}{|c|c|c|c|c|c|c|c|c|c|}
\hline \multirow[b]{2}{*}{ Compound } & \multicolumn{4}{|c|}{ ST } & \multicolumn{4}{|c|}{ ID } & \multirow{2}{*}{$\begin{array}{l}\mathrm{ST} \times \mathrm{ID} \\
p \text {-value }\end{array}$} \\
\hline & 0 days & 15 days & 30 days & $p$-value $(\mathrm{n}=54)$ & 0 kGy & $0.50 \mathrm{kGy}$ & $3.00 \mathrm{kGy}$ & $p$-value $(\mathrm{n}=54)$ & \\
\hline C14:0 & $0.14 \pm 0.02$ & $0.14 \pm 0.02$ & $0.13 \pm 0.02$ & 0.267 & $0.13 \pm 0.02$ & $0.13 \pm 0.02$ & $0.15 \pm 0.02$ & 0.005 & 0.023 \\
\hline $\mathrm{C} 16: 0$ & $14 \pm 1$ & $14 \pm 1$ & $13.5 \pm 0.5$ & 0.470 & $13 \pm 1$ & $13.6 \pm 0.5$ & $14 \pm 1$ & 0.089 & 0.002 \\
\hline C16:1 & $0.37 \pm 0.04 \mathrm{a}$ & $0.36 \pm 0.04 \mathrm{a}$ & $0.32 \pm 0.05 \mathrm{~b}$ & 0.004 & $0.35 \pm 0.04$ & $0.34 \pm 0.04$ & $0.37 \pm 0.05$ & 0.084 & 0.556 \\
\hline $\mathrm{C} 17: 0$ & $0.11 \pm 0.02$ & $0.12 \pm 0.01$ & $0.13 \pm 0.01$ & $<0.001$ & $0.12 \pm 0.01$ & $0.12 \pm 0.01$ & $0.11 \pm 0.02$ & 0.068 & 0.027 \\
\hline $\mathrm{C} 18: 0$ & $0.82 \pm 0.05 \mathrm{~b}$ & $0.89 \pm 0.05 \mathrm{a}$ & $0.83 \pm 0.05 \mathrm{~b}$ & 0.001 & $0.82 \pm 0.04 \mathrm{a}$ & $0.86 \pm 0.05 \mathrm{a}$ & $0.87 \pm 0.05 \mathrm{a}$ & 0.042 & 0.862 \\
\hline C18:1n9 & $32 \pm 3$ & $30 \pm 4$ & $34 \pm 2$ & 0.003 & $32 \pm 4$ & $33 \pm 3$ & $31 \pm 3$ & 0.045 & 0.007 \\
\hline C18:2n6 & $45 \pm 2$ & $47 \pm 3$ & $44 \pm 2$ & 0.003 & $45 \pm 3$ & $44 \pm 2$ & $46 \pm 2$ & 0.076 & 0.002 \\
\hline C18:3n3 & $6 \pm 1 \mathrm{a}$ & $6 \pm 1 \mathrm{a}$ & $5 \pm 1 \mathrm{~b}$ & 0.002 & $6 \pm 1 \mathrm{ab}$ & $5.5 \pm 0.5 \mathrm{~b}$ & $6 \pm 1 \mathrm{a}$ & 0.018 & 0.359 \\
\hline $\mathrm{C} 20: 0$ & $0.36 \pm 0.02$ & $0.37 \pm 0.03$ & $0.36 \pm 0.03$ & 0.230 & $0.35 \pm 0.02$ & $0.37 \pm 0.04$ & $0.36 \pm 0.02$ & 0.213 & 0.005 \\
\hline $\mathrm{C} 20: 1$ & $0.65 \pm 0.05$ & $0.65 \pm 0.05$ & $0.69 \pm 0.05$ & 0.018 & $0.67 \pm 0.05$ & $0.70 \pm 0.05$ & $0.61 \pm 0.05$ & $<0.001$ & 0.001 \\
\hline $\mathrm{C} 22: 0$ & $0.26 \pm 0.02$ & $0.31 \pm 0.04$ & $0.27 \pm 0.03$ & $<0.001$ & $0.27 \pm 0.03$ & $0.28 \pm 0.05$ & $0.29 \pm 0.03$ & 0.458 & 0.020 \\
\hline $\mathrm{C} 24: 0$ & $0.14 \pm 0.02$ & $0.18 \pm 0.03$ & $0.15 \pm 0.03$ & $<0.001$ & $0.15 \pm 0.03$ & $0.17 \pm 0.03$ & $0.15 \pm 0.03$ & 0.017 & 0.017 \\
\hline SFA & $15.6 \pm 0.5$ & $16.0 \pm 0.5$ & $15.5 \pm 0.5$ & 0.100 & $15.5 \pm 0.5$ & $15.7 \pm 0.4$ & $16.0 \pm 0.5$ & 0.048 & 0.004 \\
\hline MUFA & $33 \pm 3$ & $31 \pm 4$ & $35 \pm 2$ & 0.003 & $33 \pm 4$ & $34 \pm 3$ & $32 \pm 3$ & 0.038 & 0.006 \\
\hline PUFA & $51 \pm 2$ & $53 \pm 4$ & $50 \pm 2$ & 0.006 & $52 \pm 4$ & $50 \pm 3$ & $52 \pm 3$ & 0.042 & 0.018 \\
\hline
\end{tabular}


Table 3. Composition in tocopherols $(\mathrm{mg} / 100 \mathrm{~g} \mathrm{dw})$ of Turkish chestnuts according with irradiation dose (ID) and storage time (ST) (mean $\pm \mathrm{SD})$.

\begin{tabular}{lllll}
\hline & & $\alpha$-tocopherol & $\gamma$-tocopherol & $\delta$-tocopherol \\
\hline \multirow{4}{*}{ ST } & 0 days & $0.0019 \pm 0.005 \mathrm{~b}$ & $1.0 \pm 0.2$ & $0.07 \pm 0.02$ \\
& 15 days & $0.0027 \pm 0.005 \mathrm{a}$ & $1.0 \pm 0.1$ & $0.07 \pm 0.02$ \\
& 30 days & $0.0022 \pm 0.004 \mathrm{~b}$ & $1.0 \pm 0.1$ & $0.06 \pm 0.01$ \\
& $p$-value $(\mathrm{n}=54)$ & 0.004 & 0.136 & 0.017 \\
\hline & & & & \\
ID & $0.00 \mathrm{kGy}$ & $0.0026 \pm 0.005 \mathrm{a}$ & $1.0 \pm 0.2$ & $0.07 \pm 0.02$ \\
& $0.5 \mathrm{kGy}$ & $0.0021 \pm 0.004 \mathrm{~b}$ & $1.0 \pm 0.2$ & $0.07 \pm 0.02$ \\
& $3.00 \mathrm{kGy}$ & $0.0021 \pm 0.005 \mathrm{ab}$ & $1.0 \pm 0.1$ & $0.06 \pm 0.011$ \\
\hline ST $\times$ ID & $p$-value $(\mathrm{n}=54)$ & 0.028 & 0.209 & 0.087 \\
\hline
\end{tabular}




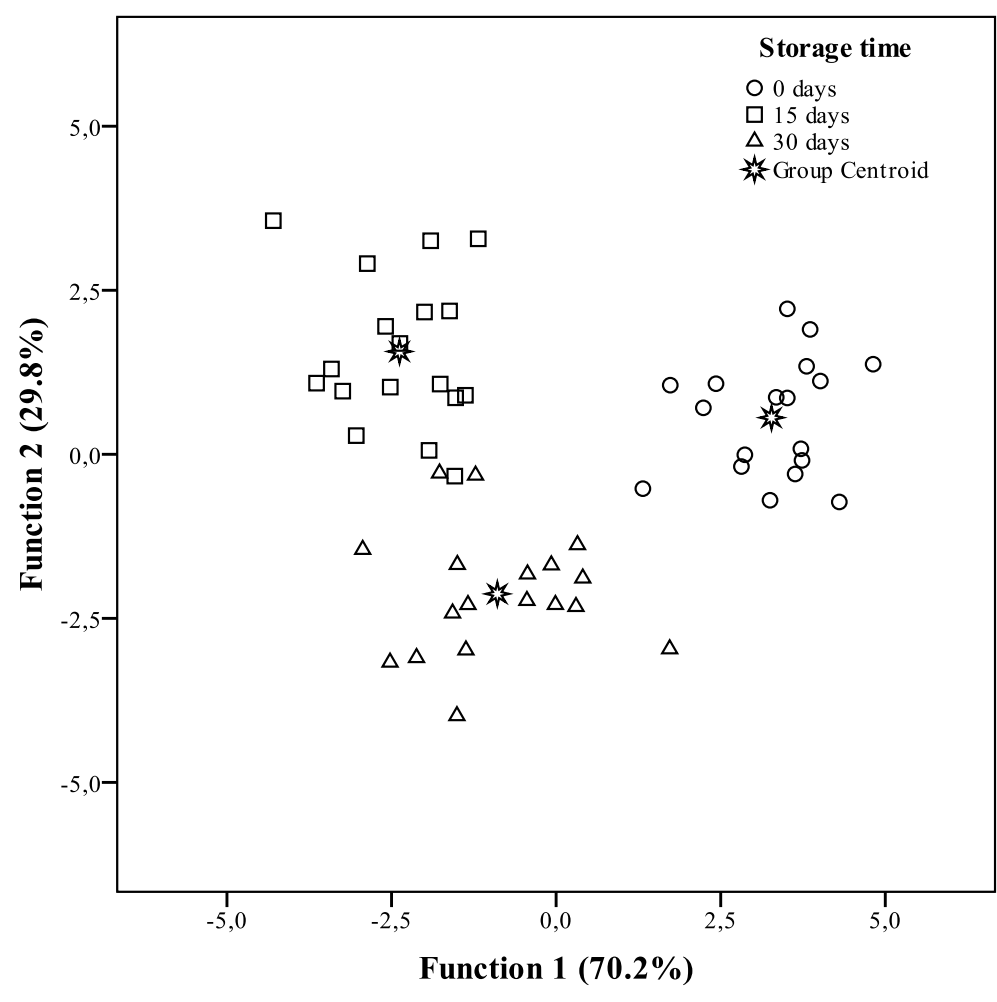

(A)

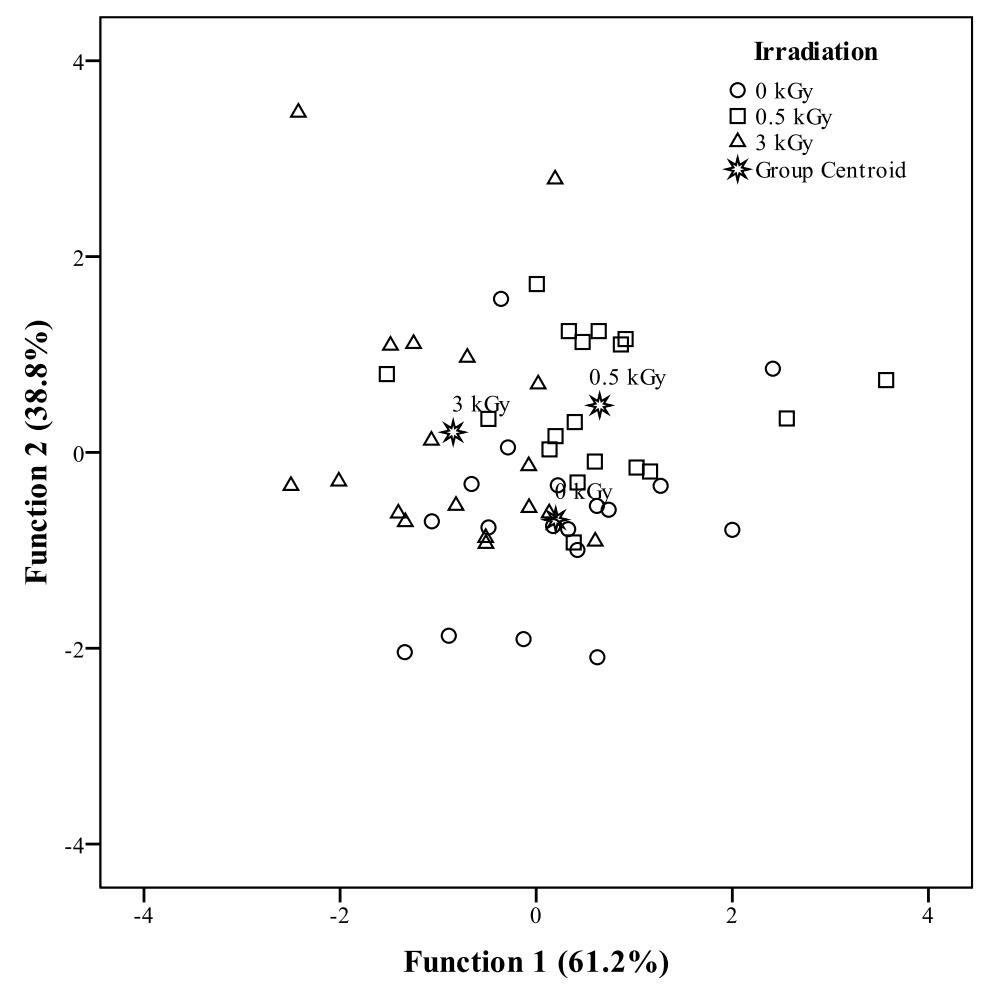

(B)

Fig. 1 Canonical analysis of (A) storage times base on fatty acids profile and (B) irradiation doses influence based on all the parameters of Turkish chestnuts. 